\title{
FRESH AND PRESERVED COCONUT MILK
}

\author{
Robert Hagenmaier ${ }^{1}$
}

\begin{abstract}
This article was written with two goals. The first is to show that coconut milk is an important product, at least to those in volved in the production of coconuts. The second is to suggest how the market for preserved coconut milk might be expanded.

We will first review how coconut milk is consumed, for what purposes and in what quantity. Next we will look at the different kinds of preserved coconut milk. Finally, we will consider how the market for preserved coconut milk might be bolstered by standardizing its quality.
\end{abstract}

\section{What is Coconut Milk?}

Coconut milk is the milky, white liquid squeezed out from grated coconut meat. It is optional whether or not water is added to help separate the milk from the fibrous cell walls that are left behind.

The oil found in coconut milk is of key importance. Chemically speaking, coconut milk is an oil-in-water emulsion, with oill content of approximately $35 \%$ if no water is added in the extraction process. Functionally, coconut milk is a oil-based flavoring ingredient. This is important fact for the coconut industry, because as yet there is no good substitute for natural coconut flavor. Nutritionally, coconut milk is mainly a source of calories, $90 \%$ of which are contributed by the oil. Finally, because of its very high oil content, coconut milk is too rich to be consumed in pure form. Instead, it is always mixed with other food substances before it is consumed.

In Indonesia coconut milk is called 'santan-santan.' in Malaysia-Singapore it is 'santan,' in Sri Lanka 'Pol Kiri', in the Philippines 'gata,' and in English sometimes 'coconut cream'.

\section{How is Coconut Milk Used?}

Coconut milk is used in such a large variety of foods that to understand how it is used means that we must consider extensive information on diets. Moreover, the necessary information is poorly documented because coconut milk is not a popular item of commerce - it is usually prepared and used in the kitchen. One way to get the information would be to survey dietary pattems, but that is a big undertaking.

The dietary information that we will use comes from cook-books, of which a number were surveyed. The most comprehensive was the Time-Life series "Foods of the World" (1968-72). In that collection there are many coconut recipes, all included in recipes used in coconut-producing countries. For the Asian Pacific region about $17 \%$ of the recipes that were given called for coconut milk as one of the ingredients (Steinberg, 1970). For both Africa and Latin America, coconut mflk was an ingredient in some 5\% of the recipes (Leonard, 1968: van der Post, 1970). No coconut milk recipes were found in the Time-Life books for non-coconut-producing regions.

\footnotetext{
${ }^{1}$ Author of 'Coconut Aqueous Processing', San Carlos Publications, University of San Carlos. Cebu City, Philippines.
} 
In a separate collection of 300 Asian recipes, 58 call for coconut milk (Vista, 1979). None of the 95 Chinese, Japanese and Korean recipes called for coconut milk; rather, all of the 58 coconut-milk recipes were from coconut producing countries. For comparison, only 7 of the 300 recipes called for other forms of coconut (grated meat or desiccated coconut) - thus suggesting the relative importance of coconut milk versus other food uses of coconut.

For the sources just cited, there were 124 recipes that called for coconut mflk as an ingredient, divided as follows between these different types of dishes

$\begin{array}{ll}\text { Seafood } & 31 \\ \text { Poultry } & 20 \\ \text { Dessert } & 20 \\ \text { Meat } & 19 \\ \text { Vegetable } & 17 \\ \text { Rice } & 13\end{array}$

These flgures reflect the fact that in coconut-producing countries coconut is used quite differently from the way it is used in Western countries, where most coconut is used in sweets and dessert dishes - rarely in the form of coconut milk.

The 124 recipes calling for coconut milk were divided amongst countries as follows:

$\begin{array}{lc}\text { Indonesia } & 39 \\ \text { Malaysia } & 17 \\ \text { India } & 12 \\ \text { Thailand } & 10 \\ \text { Sri Lanka } & 6 \\ \text { Burma } & 6 \\ \text { Mozambique } & 5 \\ \text { Singapore } & 5 \\ \text { Tahiti } & 5 \\ \text { Kampuchia } & 4 \\ \text { Philippines } & 4 \\ \text { Brazil } & 3 \\ \text { East Africa } & 2 \\ \text { Venezuela } & 2 \\ \text { Hawaii } & 1 \\ \text { Borneo } & 1 \\ \text { Colombia } & 1 \\ \text { Laos } & 1\end{array}$

That is all the information we will derive from the recipe collections. Lest it be concluded that too many conclusions have already been milked from too little information, it might be worthwhile remarking; that ten other recipe collections were reviewed before selecting Time-Life and Vista as being fairly representative. 


\section{HOW MUCH COCONUT MILK IS CONSUMED?}

While coconut-milk usage is poorly documented, there are readily-available statistics on trade and markets for coconut as crop and also for that portion made into copra. Statistics on fresh coconut consumption are scarce, even though "it has been estimated that, world-wide, just over half the volume of coconuts is consurned fresh" (FAO, 1979)

Table 1 shows statistics for 16 countries that altogether produce some $93 \%$ of coconuts and $95 \%$ of copra. Please note that for column (c) the copra production has been converted to the equivalent weight of the dehusked nuts from which the copra was produced.

Table 1. Coconut and Copra Production for 1983

\begin{tabular}{|l|r|r|r|}
\hline & $\begin{array}{r}\text { Coconut } \\
\text { (M.T.) (a) }\end{array}$ & \multicolumn{1}{|c|}{$\begin{array}{c}\text { Copra } \\
\text { (M.T.) (b) }\end{array}$} & $\begin{array}{r}\text { Coconut Equiv of } \\
\text { Copra (M.T.) (c) }\end{array}$ \\
\hline World & $34,890,000$ & $4,548,000$ & $19,070,000$ \\
Africa & $1,554,000$ & 177,000 & 742,000 \\
North/Central America & $1,443,000$ & 192,000 & 805,000 \\
South America & 576,000 & 38,000 & 159,000 \\
Asia & $29,142,000$ & $3,835,000$ & $16,080,000$ \\
Oceana & $2,175,000$ & 306,000 & $1,283,000$ \\
Indonesia & $11,100,000$ & $1,070,000$ & $4,487,000$ \\
Philippines & $9,200,000$ & $1,930,000$ & $8,092,000$ \\
India & $3,900,000$ & 350,000 & $1,468,000$ \\
Sri Lanka & $2,300,000$ & 145,000 & 608,000 \\
Malaysia & $1,200,000$ & 204,000 & 855,000 \\
Mexico & 825,000 & 145,000 & 608,000 \\
Thailand & 800,000 & 56,000 & 235,000 \\
Papua New Guinea & 767,000 & 138,000 & 579,000 \\
Mozambique & 400,000 & 65,000 & 273,000 \\
Viet Nam & 360,000 & 64,000 & 268,000 \\
Tanzania & 320,000 & 29,000 & 122,000 \\
Vanuatu & 260,000 & 37,000 & 155,000 \\
Brazil & 241,000 & 3,000 & 13,000 \\
Solomon Islands & 230,000 & 31,000 & 130,000 \\
Fiji & 210,000 & 21,000 & 88,000 \\
Samoa & 200,000 & 18,000 & 75,000 \\
& & & \\
\hline
\end{tabular}

Notes : (a) The weight of the whole nut excluding only the fibrous outer husk, this includes all coconuts produced, whether ripe or unripe, whether consumed fresh or processed into copra or desiccated coconut (FAO, 1983, p 153, Table 46). (b) Copra production is also from FAO 1983. (c) This conversion uses 4,193 $\mathrm{kg}$ dehusked nuts as the equivalent of 1,000 $\mathrm{kg}$ copra (UCAP, 1983).

The amount of coconut not made into copra can be deduced from Table 1 by subtracting the figures in column (c) from those in column (a). The results of such a calculation aThe shown in Table 2, together with per-capita figures.

From Table 2 we see that Indonesia, India and Sri Lanka together account for over half the coconuts used for purposes other than making copra. Altogether, the 16 countries listed in Table 2 account for some $75 \%$ of coconuts not made into copra. 
Those coconuts not made into coora. include both mature and immature coconuts. See Table 1, Footnote (a). A large percentage of the mature coconuts are made into coconut milk. Immature coconuts, on the other hand, areused as a source of coconut water, never for making coconut milk. Thus, the inclusion of immature 6oconuts in the FAO statistics means we must now turn to data from other sources.

Table 2. 1983 Production of Coconuts that were not made into Copra.

\begin{tabular}{|l|r|r|r|}
\hline & $\begin{array}{r}\text { Coconuts Not Made } \\
\text { Into Copra (M.T.) }\end{array}$ & $\begin{array}{r}1983 \\
\text { Population }\end{array}$ & $\begin{array}{r}\text { Non-Copra Coconuts } \\
\text { Per Capita (kg/yr) }\end{array}$ \\
\hline World & $15,820,000$ & & \\
Africa & 812,000 & & \\
N/C America & 638,000 & & \\
So. America & 417,000 & & \\
Asia & $13,062,000$ & & \\
Oceana & $2,175,000$ & & \\
Indonesia & $6,613,000$ & $156,000,000$ & 42.0 \\
India & $2,432,000$ & $725,000,000$ & 3.4 \\
Sri Lanka & $1,692,000$ & $15,800,000$ & 107.0 \\
Philippines & $1,108,000$ & $53,000,000$ & 21.0 \\
Thailand & 565,000 & $50,000,000$ & 11.0 \\
Malaysia & 345,000 & $7,200,000$ & 48.0 \\
Brazil & 238,000 & $131,000,000$ & 1.8 \\
Mexico & 217,000 & $76,000,000$ & 2.9 \\
Tanzania & 198,000 & $19,700,000$ & 10.0 \\
Papua New Guinea & 188,000 & $3,400,000$ & 55.0 \\
Mozambique & 127,000 & $11,400,000$ & 11.0 \\
Samoa & 125,000 & 160,000 & 781.0 \\
Fiji & 122,000 & 660,000 & 185.0 \\
Vanuatu & 105,000 & 130,000 & 808.0 \\
Solomon Islands & 100,000 & 260,000 & 385.0 \\
Viet Nam & 92,000 & $57,000,000$ & 1.6 \\
\hline
\end{tabular}

Direct estimates of coconut milk consumption were made by Adair and Marter (1983). In terms of coconuts per capita used for coconut milk, they reported annual consumption to be the following:

\begin{tabular}{cccc} 
Indonesia & \multicolumn{3}{c}{ Thailand } \\
Rural & 15 & Rural & 12 \\
Urban & 19 & Urban & 12 \\
SriLanka & & Westem Sarnoa \\
Rural & 88 & Rural & 180 \\
Urban & 76 & Urban & 180 \\
Philippines & & Singapore & 2 \\
Rural & 3 & & \\
Urban & 1.5 &
\end{tabular}

We now combine the figures of Adair and Marter with those of FAO, taking 900 grams as the average weight of a dehusked coconut. The result is that in Indonesia about $40 \%$ of the noncopra coconuts are used to make coconut milk. In Sri Lanka the corresponding figure is $75 \%$ and in 
Thailand almost $100 \%$. In these and most coconut-producing countries a substantial percentage of non-copra nuts are converted into coconut milk. The outstanding exception is the Philippines, where only about $10 \%$ are so used.

On the average about half of non-copra coconuts are made into coconut milk. This leads us to conclude that about 7,900,000 M.T. dehusked coconuts are used annually to make coconut milk (half of 15,820,000 M.T. see Table 1). Thus, coconut milk is made from some $23 \%$ of all coconuts produced - probably more than are used for any other product save edible oil.

It. is interesting to note that coconut milk has achieved a position of such importance, not because of any organized marketing efforts on its behalf, but because millions of people think that coconut milk adds enough flavor to justify the work of grating the meat and squeezing out the milk.

\section{SUPPLY OF COCONUT MILK}

The sources of coconut milk known to this author are these.

1. The liquid squeezed from fresh coconut meat,

2. that pressed from a mixture of desiccated coconut and water, or

3. creamed coconut; any of which may be

4. sterilized,

5. pasteurized or

6. spray-dried; and

7. artificial products made without coconut.

1. Freshly Squeezed Milk. Freshly squeezed coconut milk has excellent flavor but spoils rapidly. Spoilage is likely to be especially rapid if the consumer purchases grated meat rather than the whole coconut, since the meat shredding operations found in many food markets are very unsanitary.

2. Desiccated Coconut. Desiccated coconut is suggested in many cookbooks as an altemate raw material for makin- coconut milk when fresh coconuts are not available - and it serves very well for that purpose. The amount so used, although unknown, would be a very small part of the 130,000 M.T. of desiccated coconut exported annually (APCC, 1983) - an amount equivalent to 2,000,000 M.T. dehusked coconut (APCC, 1982). Coconut milk has good flavor and is sanitary if it is made from top-quality desiccated coconut.

3. Creamed Coconut. This product is made from desiccated coconut by reduction in particle size (creaming). The creaming operation is performed at plants in the U.K., U.S., Sri Lanka., Malaysia and the Philippines. Crearned coconut is used industrially to make ice cream. As a consurner product it is distributed in refrigerated form, especially in Europe. Its main disadvantage as a coconut-milk substitute is its sornewhat gritty mouthfeel. Crearned. coconut does not keep well if unrefrigerated - the oil separates as a separate phase, leaving the fiber to settle as a compact and difficult-to-remove layer in the bottom of the container. The advantages of crearned coconut are low cost and absence of additives (except possibly sulfites). Those in the business say total consumption of crearned coconut amounts to a few thousand M.T. yearly.

4. Sterilized Milk. Sterihzed. coconut milk can be either sweetened or unsweetened. The market for canned, unsweetened Coconut Milk was estimated by Adair and Marter (1983) to amount to 2,100 M.T. yearly. There are many manufacturers of this product. The biggest disadvantages are high price and often poor quality (tinny flavor, lumps, grey color). The advantage is convenience. 
Most of the canned, sterilized milk in the market is made from the milk squeezed from fresh coconuts. Some is made from desiccated coconut. At least one brand is made by reconstituting crearned coconut with water. A related. product (UHT-sterilized coconut milk) has been made in a smaU plant in Singapore for several years.

5. Pasteurized Coconut Milk. Like dairy milk and many other products, coconut milk can be preserved by pasteurization and refrigeration. Nevertheless, such a product does not exist on the consumer market, perhaps because home refrigeration is scarce in most coconut producing countries. In bulk quantities the product is sold: frozen, pasteurized coconut milk was, at least until recently, exported from the Philippines and Fiji.

Coconut milk is often sweetened in order to extend its shelf life. Because unsweetened coconut rnilk is a low-acid product ( $\mathrm{pH}$ above 4.6) it must receive a heat treatment equivalent to 3.0 Fo value (Pflug and Odlaug, 1976). With this amount of heat treatment the protein in coconut milk denature and cause the producf to solidify unless preventive measures are taken, such as removal of the protein or use of stabilizers. Somewhat less heat treatment is needed if the coconut milk is sweetened to lower the water activity sufficiently. The main disadvantage of sweetening coconut milk is that so much of the product is used for meat, fish, and vegetable dishes where sugar is not a desired, ingredient. Even so, most canned coconut milk sold in the U.S. is sweetened.

6. Spray-Dried Coconut Milk. Coconut milk, mixed with stabilizers, can also be preserved by spray-drying. Spraydried coconut milk, available since 1979, is now made in Thailand, Phihppines, and Malaysia. The dry product costs less than canned sterilized milk, more than desiccated or crearned coconut. It is more convenient than making fresh coconut milk, but less convenient than preserved liquid milk. The flavor is good - better than sterilized coconut milk but not as good as the freshly squeezed product. The powder must be kept in moisture-impermeable packaging, which is a disadvantage. Total production is approxiinately 1,000 M.T. annually.

Spray-dried crearned coconut, a similar product, is made from a mixture of creamed coconut, water and stabilizers. It is more stable than creamed coconut, since it remains a powder if kept dry. Disadvantages are gritty mouthfeel and fair flavor (because twice-dried). Spray-dried crearned coconut is made by one company in the United States.

7. Artificial Coconut Milk. Except for non-availability of a good coconut flavor, it would be relatively easy to formulate a suitable synthetic product. The ingredients would be approximately as follows :

\section{INGREDEENT}

Water

Vegetable Oil

Maltodextrin

Sodium Caseinate

Eniulsifiers

Flavor

TOTAL

\section{WEIGHT (grams)}

$\begin{array}{r}55.0 \\ 30.0 \\ 9.0 \\ 4.8 \\ 1.0 \\ 0.2 \\ ----- \\ \hline 100.0\end{array}$

The cost of the ingredients would be approximately $\$ 0.05$ per 100 grains, which is approximately the amount of coconut milk recovered by the cook from the grated meat of one 
coconut. As it happens, $\$ 0.05$ is a typical wholesale price of a coconut in coconut-producihg regions. The retail price about $\$ 0.15$ - although considerable variation is found.

Artificial coconut milk would have some advantages over the natural product. First, synthetic coconut milk could be made close to the point of consumption. Second, manufacturing facilities could be shared with other products, thus reducing the investment risk. Finally, there would be a more stable supply of raw material.

Probably the major obstacle to marketing a good-quality artificial product would be the difficulty of weaning the consumer from fresh-squeezed coconut mflk - but that process has already started because of marketing efforts on behalf of preserved naturai coconut milk. There could be another obstacle, namely, a marketing effort by coconut interest groups on behalf of natural coconut milk, but to date no such effort has materialized.

\section{GROWING PAINS}

Although there are a number of different types of preserved coconut milk., their combined. production probably does not amount to even one percent of total coconut milk consumption. Preserved coconut milk is a growing child whose development needs a good environment. At present the environment tends to in whit growth. Here is why.

a) Canned coconut milk has no concentration standards. It can be watered down at the discretion of the manufacturer. For example, various brands of canned, sterilized unsweetened coconut milk were found to have oil content of $10-23 \%$, which is quite a large range. (Oil content is a useful indicator of the concentration of coconut milk).

b) Names are not standardized. For example, the hquid squeezed from grated meat may be caHed "coconut milk" by one manufacturer and "coconut cream" by another. Creamed coconut is labeled by some as "coconut cream". Hence: two different products with the same name.

c) There is no enforcement of truth in labeling. Some canned coconut milk was found whose label was clearly false re the additives used;

d) Coconut milk product are sometimes made from substafidard raw material. For example, the raw material used by some manufacturers of creamed coconut is unwholesome desiccated coconut.

e) Plant sanitation is often below standard. As illustration. in one plant coconut milk was routinely made from coconut meat covered with flies.

f) As a marketing technique it is fairly common to claim that the coconut milk contained in the package is equivalent to a given number of coconuts. Unfortunately, there is no uniform basis for such claims. For example, one package may claim its contents to be equivalent to 1 coconut. Another can with less coconut solids might claim 1.5 coconuts.

g) There are no industry grades or quality standards - each company makes up his own. For example, some canned coconut milk is grey in color and lumpy in texture, some is white and smooth.

Expansion of the market for coconut milk depends very much on the availability of good-quality preserved coconut milk. This will make coconut milk available and attractive to those unable to afford the time or cost of making fresh coconut milk. In order to assist the development of the preserved coconut-milk industry I would recommend a prograrn that includes the following: 
a) Publication of standard laboratory methods to be used for coconut milk;

b) Narning of preserved coconut milk according to the processing undergone and the additives used;

c) Grading and certifying of preserved coconut milk according to moisture content, free fatty acids, rancidity, color and flavor;

d) Regular inspection of manufaturing plants

e) Rules for shelf life labeling;

Compliance could be voluntary and yet effective if there is action to persuade buyers to ask for certificates of quality. A pohcy of voluntary comphance has the advantage that the organization undertaking the prograin could be an industry group using the same standards in different countries. By contrast, government standards are likely to depend very much on the country.

\section{SUMMARY AND CONCLUSION}

It is widely recognized that new and expanded markets are needed for coconut products. Coconut milk is a product that could significantly increase the demand for coconut. Consider that at present, when about $99 \%$ is laboriously made by hand, still its use is so large that aboutonequarter of all coconuts are converted into coconut milk. Large as the market is now, there is the possibility of much growth if good-quahty preserved coconut milk were to. be made available. Unfortunately, at present the quality of the preserved product is variable and unregulated. Standardization of quality is suggested in order to aid the development of the market.

\section{REFERENCES}

Adair, D. and A. Marter, Culham, U.K, "The Industrial Production of Coconut Cream", Tropical Products Institute, UNIDO Document US/GLO/80/005. Volume 2p. 103, 1983.

APCC, Coconut Statistical Yearbook, Asian and Pacific Coconut Community, Jakarta, Indonesia, 1982.

FAO, Fats and Oils Team, Commodities and Trade Division, Rome "The World Coconut Situation and Outlook," Manila, 1979.

FAO, 1983 FAO Production Yearbook, Table 46 page 153.

Leonard, Jonathan Norton, "Latin American Cooking", and also "Recipes : Latin American Cooking", Time-Life Books, New York, 1968.

Pflug, I.F. and T.E. Odlaug, "A Review of $\mathrm{Z}$ and $\mathrm{F}$ values used to ensure the safely of low-acid canned food", Food Tech., 78 June, 1976.

Steinberg, Rafael, "Pacific and Southeast Asian Cooking", and "Recipes: Pacific and Southeast Asian Cooking", Time Life Books, 1972.

UCAP, United Coconut Association of the Philippines, "Coconuts Todays", p. 170, 1983.

van der Post, Laurens, "African Cooking : and "Recipes : African Cooking, Time-Life Books, 1970.

Vis Culinary Division, "300 Asian Best Recipes", Vista Productions Ltd., Hong Kong, 1979. 